\title{
Alexander Brome and the Search for the "Safe Estate"
}

\author{
RAYMOND A. ANSELMENT
}

\begin{abstract}
Alexander Brome no longer receives the attention he enjoyed in the seventeenth century. "Eminent in the worst of Times for Law, and Loyalty, and yet more for Poetry," Brome published three editions of Songs and other Poems in the first years of the Restoration. His translations of Horace issued separately won particular contemporary acclaim, and in the opinion of Edward Phillips' Theatrum Poetarum (1675) "among the Sons of Mirth \& Bacchus, to whom his Sack-inspired Songs have been so often Sung to the sprightly Violin, his name cannot chuse but be immortal. ${ }^{2}$ Restoration dramas alluded to Brome's songs, and the poems "compos'd during the late Troubles" contributed to the fame Gerard Langbaine notes in his 1691 survey, An Account of the English Dramatick Poets. ${ }^{3}$ With the turn of the century, however, Brome's eminence began to diminish; today he is chiefly remembered as a minor poet who supports with seemingly effortless wit the Royalist cause. ${ }^{4}$ While this judgement of his stature is not unwarranted, the modern tendency to slight Brome's poetry may be unjust. Like the diaries and the provincial records that now figure prominently in studies of the civil turmoil, Brome's Songs and other Poems offers an immediate and often unique alternative to conventional notions of the loyalties and values of war-wearied Englishmen. ${ }^{5}$
\end{abstract}

His political songs, ballads, odes, and epistles follow an admittedly homely muse appropriate to those "verseless times." Poems to his fellow poets Richard Lovelace and Charles Cotton describe a darkened world inimical to "true poesy." Unable to find perspective and audience in the enveloping upheaval, Brome does not aspire to Abraham Cowley's attempt at a civil war epic or to George Daniel's ambitions toward heroic narrative. Instead he argues half-seriously that the fantastical events of the present best suit the ballad: "For a man may be furnished with so much matter, / That he need not lie, or rail, or flatter" (I, 214). Less ironically he refers to his poems as "harmelesse lines" written to amuse himself and selected friends with "short and sweet delight" (I, 244). While the light-hearted drinking song and the simple ballad provide a ready mode for such amusement, their personae and tone often reveal a complexity at odds with such avowals of simplicity. 
Except for the epistles, which seem generally written in propria persona, Brome's ballads, odes and songs express a range of voices from across the social and political spectrum. At the outset of Songs and other Poems, a prose epistle cautions the reader that the author's beliefs must not be confused with the speaker's attitudes: "those Odes which may seem wild and extravagant [are] not to be Ideas of my own mind, but characters of divers humours set out in their own persons. And what reflected on the Times, to be but expressions of what was thought and designed by the persons represented; there being no safe way to reprove vices then raging among us, but to lash them smilingly" (I, 51). Failure to heed this distinction, in fact, explains the modern judgement that his poems are "sour little songs ... eloquent of a bitterness which, in the end, lacks all nobility and degenerates to an ill-tempered sneer." ${ }^{\text {"7 }}$ Brome, who earlier had written a successful play, creates another form of drama in this pageant of figures that shows a country in revolution groping for identity. Through critical scrutiny of these characters, Brome himself attempts to come to terms with the national upheaval.

The satiric devices of inversion and self-revelation give immediacy to the satires' ironic portraiture. In "The Saints Encouragement" the refrain "The clean contrary way" underscores the absurdity of a zealous reformer who presumably can see no contradiction when, for example, he declares,

We subjects Liberties preserve,

By prisonment and plunder,

And do inrich our selves and state

By keeping the wicked under. $(I, 208)$

A similar call to arms in "The Scots Curanto" sees that the Scots thrive on the English difficulties; without any illusions about principle, its cynical speaker gloats that the pretence of reformation will "tickle the minds of the giddy-brain'd rout" and "We'l gain by their loss and folleys" $(I, 211)$. The same call taken up in "The Levellers rant" blurs greed and ideology, but once again the sinister implications are not lost in the speaker's claim,

'Tis no lesse then treason,

'Gainst freedom and Reason

For our brethren to be higher then we. (I, 127)

When religious reform becomes a "matter of trade" as it is in "The Holy Pedler," and Parliament proves to be little more than the charlatan of "The New Mountebanck," the country seems hopelessly caught in the grasp of rapacious victimizers.

Brome's depiction of this blatant greed implies the reaction of a tradition- 
alist. The earliest of the dated poems, "An Ode. Written in 1643," leaves no doubt about the disorder that will follow now that the lesser stars and planets have pushed the figurative sun from its rightful course and the "blind Phaetons" have seized control. The poem's conventional imagery and warning suggest the loyalty to the king and sense of natural order developed explicitly in "A Serious Ballade. Written in 1645":

I love the King and the Parliament

But I love them both together;

And when they by division asunder are rent,

I know 'tis good for neither. (I, 219)

The hope in the poem's refrain that "the King and his Realmes agree" values a harmony premised on the assumptions that the parliament remains subordinate, religion unsullied, and the law undisturbed. Or as the "good subject" concludes in a poem written the year before,

One God, one King,

One true Religion still;

In every thing

One Law both should fulfil. (I, 172)

From this perspective threats to this unity quite naturally appear the forces of ambition and anarchy personified.

While other contemporary ballads and songs also decry a mercenary, lawless age, Brome's poetry is uniquely sensitive to the confusions and frustrations of the faction-ridden time.$^{8}$ The long account of misfortune narrated by the rustic in "The Clown" makes much the same point as the equally desperate voice in "The Commoners": the average citizen is subject to the whims of the powerful and "all are undone for ever" $(I, 118)$. The maddening contradiction of a war ostensibly fought for the peace of the nation is also painfully apparent to the speaker of "The Riddle." "Good subjects" cannot win, whichever side ultimately triumphs; caught between factions that threaten their lives and property, they can only hope peace will come before they too are "undone." Even in the early stages of the war, before the royalist cause seemed doomed, Brome has no illusions about its destructive course; later events only strengthen the poems' insistence on the social and economic victimization of the country.

Brome refuses to admit that the political and religious principles are anything more than a pretext for ambition. In a poem welcoming the restoration of Charles II, the speaker insists that the sword had displaced the law and the three nations had been inflamed so that individuals bent on revenge and advancement could rob those they pretended to help. " " $\mathrm{A}$ Satyre on the Rebellion" composed during the bleak period of royalist 
fortunes similarly denounces the economic hardships "loyal Subjects" must endure when those in power "know no other godliness but gain" (I, 284). At greater length and detail the speakers in "The Reformation" and "On Sir G.B. his defeat" stress the incessant desire to get ahead at the expense of the ordinary people, "we commons." In some of his most forceful lines Brome portrays the greed and destruction endemic in a society whose only law is "That side is always right that's strong, / And that that's beaten must be wrong"' $(I, 168)$. The Hobbesian vision is one of tradesmen, lawyers, and clergy struggling unscrupulously to advance themselves:

Tell not me of Lords or Lawes,

Rules or Reformation,

All that's done's not worth two strawes,

To the welfare of the Nation. $(I, 162)$

Characteristically Brome insists the current struggle is merely part of the timeless spectacle of human vanity in which "All the world keeps a round." The circular pattern of rising and falling movement he sees in "this mad age" imposes a cosmic rhythm upon the particular events. From this perspective the English revolution changes little:

Since that which has been done's no more,

Than what has oft been done before,

And that which will be done agen,

As long's there are ambitious men,

That strive for domination. (I, 166)

Where fortune seems to dominate, would-be reformers are doomed to the fate of unscrupulous Englishmen who "turn with every wind and tide,/ Puff'd on by Ignorance and pride" (I, 163).

Brome's response to the horror of civil war embodies, in essence, the attitudes of two other works included in Songs and other Poems: a paraphrase of the first chapter of Ecclesiastes and a translation of Lucian's "Essay of the Contempt of Greatnesse." The biblical vision of pointless, circular existence and the classical attack on the hollowness of status are echoed in Brome's sceptical scrutiny of the human inclination to gratify "palat, pride, and lust." Ecclesiastes in particular provides Brome, as it did Francis Quarles, with an outlook "Very Seasonable and Vsefull for these Times." 10 Although he paraphrases only the first chapter, Brome replicates much of Ecclesiastes in his poems' various, sometimes shifting, responses to an uncertain world.

"The Royalist" typifies Brome's reaction to the troubling times. At the head of the section of political poems in all three editions, this drinking song has obvious similarities with Lovelace's "To Althea, from Prison" 
and L'Estrange's "The Liberty and Requiem of an imprisoned Royalist." Each celebrates the unvanquished spirit of the loyal subject, likening the prisoner to a bird who though encaged continues to sing. Missing from the Cavalier trinity of wine, women, and song ${ }^{11}$ in Brome's poem, however, is an inspiring Althea; women in fact have little role in his political songs and ballads. ${ }^{12}$ The king's misfortune does receive attention, though Brome dwells considerably less than L'Estrange on the ennobling example of the monarch's patient suffering. "The Royalist" seeks instead to uplift the spirit through carousing song that promises to imitate the whirling, unstable world with the spirit of sack. All cares will cease to matter, and in the motion a new order may emerge:

Our selves will be a Zodiack,

And every mouth shall be a sign.

Me thinks the Travels of the glasse,

Are circular like Plato's year,

Where every thing is as it was;

Let's tipple round; and so 'tis here. $(I, 118)$

The conceit offers a ready means of wit and resolution in many of Brome's drinking songs and catches. Confronted with a cosmic disorder, the carousing speakers often propose their own universe. Drink-flushed faces become stars or heavens, and the circular motion of the round and the tipsy spinning of the head vie with the movement of the planets. The ingenuity with which Brome explores the traditional view of microcosmmacrocosm is soon exhausted in repetitious variations common to other Cavalier drinking songs, ${ }^{13}$ but the illusion of transforming if not transcending existence continues to hold the poet's attention. The bulk of his political songs recognize the revivifying power of the cup and affirm the biblical belief "There is nothing better for a man, than he should eat and drink."

Some of the songs, like "The Royalist," seek to bolster loyal spirits through a camaraderie associated with the mirth of sack, but often the poems simply welcome the escape from oppressive reality in the carefree pleasures of drinking. Those who form the circle and keep the round disavow the intrigue and treachery of the "Giddy-brain'd times" and lift their goblets and spirits. Wine-inflamed faces become a symbol of the royal blood, and all who wear these badges of loyalty are peers; "He that won't drink and sing, / Is a Traytor to's King" (I, 174). Invigorated by the purifying qualities of sack "divinely" inspired carousers are for the moment "active to do what our Rulers require us, / And attempt such exploits as the world shall admire us" (I, 126). ${ }^{14}$ Others who embrace the world of fellowship extolled in "The Club" and the remedy prescribed in "The Cure of Care" banish all melancholy and measure time solely in terms of 
the mirth in drinking. With a devil-may-care shrug they are quick to declare "Pox on this grief" and "a fig for death or undoing." Free-flowing canary and rounds of sack are the only solace for speakers who find no profit in civil dissension and who appreciate blithe spirits. ${ }^{15}$

In a more serious vein the poems seek the consolation of the cup with a distinctly critical attitude. The exuberant preference for drinking loses its simple, jaunty tone and the invitation to forget worry carries a scornful note underscored in the repeated stress on the rapaciousness of war. Convinced that money must be spent on wine before it falls into the hands of troopers and certain that neither side can do them anything but harm, the speakers insist,

'Twixt Square-head and Round-head

The Land is confounded,

They care not for fight or battle,

But to plunder our goods and cattle. $(I, 210)$

In the end some turn to the freedom of the tavern and the consolation of drink because they offer the only refuge from the surrounding treachery. Others threatened by greed and uncertainty attempt to find solace beyond simple escapism.

At issue in these poems written during the time of royalist defeat is the fundamental tension between "The Polititian" and "The Antipolititian." Neither poem expresses any illusions about a world where fate, time, and fancy keep the "grand wheel" ever turning; "The Polititian," however, develops a more biting, cynical tone which in the end determines the speaker's resolve. Where "The Antipolititian" espouses the good cheer of wine and companionship, a life removed from politics in which all "can safely think and live, / And freely laugh or sing"' (I, 156), "The Polititian" accepts the world on its own terms, satisfied that only fools will lose themselves. Its decision to "act and juggle as others do, / Keep what's our own, get others too" (I, 149) flaunts self-interest. Honesty and love have no value among "wise" men, "For he that sticks to what his heart calls just, / Becomes a sacrifice and prey / To the prosperous whirlegigs lust" (I, 149). The cynicism of "The Polititian" takes to an extreme the premise that the safest estate lies in careless self-enjoyment; its companion piece holds out the more optimistic possibility of safety without compromise. Other poems of the same period wrestle with the implications of these divergent views.

None of these poems embraces the predatory amorality of "The Polititian,"16 but some do recognize the value of timeserving. While admonishing fellow Englishmen to keep a stout heart and a full cup, "The Cheerful heart" cheerfully endorses flattery, secure in the belief that the powerful will eventually fall and "We will serve them at last, / As they 
serv'd those that have been above "um" (I, 158). The speaker in "The Royalists Answer" concurs; shrewd subjects will appear innocuous and submissive until they can profit from the folly of their oppressors. Both poems recognize the way of the world detailed in "A New Ballad." Looking back at the fortunes of his countrymen during the last two decades, the speaker of this ballad marvels at the ironic outcome of the whirling events. Rebels who sought to destroy the monarchy and parasites who bled the nation during the commonwealth now push aside loyal Cavaliers in their eagerness to ingratiate themselves with the new king, and once again the real sufferers are people with neither the position nor the wealth to accommodate the times. This pattern, evident during both the commonwealth and the reestablished monarchy, is history's obvious lesson:

If the times turne about 'tis but to comply,

And make a formal submission,

And with every new power to live and die,

Then they are in a safe condition. (I, 216)

The same view of history, however, more often prompts Brome's speakers to reject rather than join the times. Convinced that flattery, position, and wealth play central roles in an "idle, empty pageant" they seek the contentment of a detached estate. "The Advice" and "The safe Estate" value the happiness that a long tradition of seventeenth-century writers adapt from the classical and biblical emphasis on living within means and according to reason. Wine and good fellowship again play a central role, and the poems in this vein also place a premium on the quiet life free from the burdens of money and state. Brome's speakers agree with the biblical commentary on Ecclesiastes "that in all occurrēces and chances of thys lyfe, we should liue cōtented wyth our present estate" secure with "tranquility of minde" and at ease with a "chearfulnesse of heart." 17 With confidence the placid and contented can follow the suggestion of "The Antipolititian": they can "Let the times run on their course," knowing "opposition makes them worse"; and, more importantly, they can "laugh at the whole world, and its folly."18

Laughter is the suitable response to a spectacle that merits neither love nor hatred. Both "The New Gentry" and "The Leveller" argue that envy and awe give power to positions without inherent worth; honour should only be accorded to the just and noble who strive to develop their virtues in the service of their country. The abstract phrase "noble, pow'rful, wise, and just" ${ }^{19}$ envisions an inner strength and outward constancy detailed at greater length in the catalogue of commonplaces that "Satisfaction" ascribes to the "honest, pure, and just" individual willing to risk his life for his principles. Given immediacy in a short and strained poem "Upon the King's imprisonment," the virtues dramatized in Charles' response to his 
great wrong constitute a patient, unmovable heroism. But the unshakable, even Stoic fortitude represented in the king's declarations that "my mind is free" and "your very gaol my liberty" (I, 294) is the exception. The speaker of "The Safety" who proclaims "My mind is a Kingdom" $(I, 129)$ does not celebrate his own virtue; instead like the speakers in other political poems he emphasizes detachment. The happy individual scorns the whirligig of political life because he has no illusions about its nature and his "soul is quiet and free, / And liveth content with his own" (I, 145).

At its most earnest the attitude towards self-containment becomes the religious vision of contemptus mundi. Two similar poems of loss, one on the calamitous progress of the war and the other on the death of Charles I, move inexorably to the conclusion that faith provides the only consolation in an otherwise treacherous world. The insistent repetition of the phrase "Trust not" in both the meditation "On the loss of a Garrison" and the elegy "On the Kings death" emphasizes a particularly bleak outlook. In their attempts to put defeat and death into perspective, each poem fortifies the soul with the belief that uncertainty and betrayal are inevitable parts of daily life. Relentless pessimism dismisses friendship, wisdom, and honour as well as power, wealth, and policy. Only one refuge remains:

Our only trust is in the King of Kings,

To wait with patience the event of things;

He that permits the Fathers tumbling down,

Can raise, and will, the Son up to the crown. $(I, 298)$

For someone who had seen the revolution challenge and destroy the established church and government, the wisdom of Ecclesiastes might seem inescapable. Brome's extensive paraphrase of the first chapter, in fact, suggests his own vision of a world in which "all's vanity, and the souls vexation" (I, 337), and he might naturally agree with seventeenth-century commentators that "The drift of Solomon in this Book" confirms "true happinesse here in this life cannot be attained by the enjoyment of any thing in the world." 20 Patience and faith are then logical responses to troubled times, suitable to the meditative and elegiac modes in which the speakers contemplate the loss of the garrison and the death of Charles. But that the contemptus mundi strain reflects Brome's ultimate position is not at all certain.

One moment the traditional ideals of patience and faith appear desirable, and at another the escapism of sack and the pragmatism of timeserving predominate. Even the earliest poems, however, stress the futility of the civil conflict, and time seems to deepen the awareness that "war is become a trade." Faced with this bitter knowledge, the poems written near 1648 and after abandon their lightheartedness and develop increasingly the sceptical, questioning manner of Ecclesiastes. But though their moods and 
resolutions change, the poems do not succumb completely to despondency and cynicism. They share, instead, the desire to make the best of a difficult time without losing perspective or disengagement. Their realistic attitude is strikingly clear when Brome speaks in propria persona in the epistles and elegies written for his friends.

A playfully urbane poem addressed to Charles Steynings and another epistle written to Tom S. draw into sharp focus the emphasis in the political poems on a desirable "safety and delight." Recognizing that immediate loyalties cannot and perhaps need not be decided, Brome questions the possibility of any commitment to the just side:

You always took that side that's right,

But when Charles with himself did fight,

Pray of which side were you? (I, 251)

Forthrightly he encourages his friend not to concern himself with affairs of state since no one will agree upon the wise and honest course. For his own part he confesses, "I've been for th' middle twenty years" (I, 252). His willingness to adjust this position to the whims of the moment is borne out of the belief that whatever misguided forces prevail time "keeps a round." Those mindful of their well being, it follows, will not overly trouble themselves with the changing pageant:

Let the times run, and let men turn,

This is too wise an age to burn,

Wee'l in our Judgment hover,

'Till 'tis agreed what we must be. $(1,253)$

Brome's nonchalance is, of course, partly friendly banter. Other epistles hope for the reestablishment of justice and peace, "When men turn right, and only years turn round," and at no time do the realities of the whirling times force Brome to endorse Cromwell or the interregnum governments. ${ }^{21}$ Exaggerated unconcern may be, then, a defense against the painful events of rebellion, and for the moment common sense may seem the only guide. Reduced to homely terms, the preoccupation in the other songs and ballads with personal security and the "safe estate" becomes the suggestion that Tom S. had better "mind what will cloath ye, and feed ye" (I, 259). In circumstances favouring power without regard to right, the prudent will, as he reminds Steynings in another epistle, "Stick to the strongest side, and think, and laugh."'22

The same attitude, moreover, leaves room for Brome to admire friends who steadfastly refuse to compromise. Another epistle to Tom S. commending his publication of a "pious and learned Book" shows no reluctance to praise the minister's commitment to the "constant, pure, and true." ${ }^{23}$ In contrast to the proud, greedy reformers who sought to advance their own 
fortunes under the guise of religious principle, Brome lauds the fortitude Tom S. displayed during the assault mounted against the traditional religion. With an unusual vigor and conviction the poem extols in the character of his friend the selfless virtues that enabled him in the midst of revolution to hold his position "Fix'd as the poles, whiles they kept twirling round" (I, 288).

Brome's favorite conceit also delineates the lives of friends he commemorates in elegies. The elegy traditionally sanctions extreme praise and mournful consolation, but the poems on the deaths of Aubrey, Shute, and Hearne have even greater forcefulness in the context of the times. All three elegies see that a country whose universe seems "out of course" places extraordinary demands on principled individuals who are often at odds with the new direction. The elegies on Aubrey and Shute in particular stress the corruption in religion and law that favors hypocrisy and greed at the expense of integrity and zeal. Faced with an unsympathetic, even alien world, each man displayed in his life a selfless devotion to duty that Brome clearly admires. Doctor Hearne becomes in his view an Atlas who supported the nation's health and Josias Shute "No whirlegig Lect'rer of the times" compromising biblical ideals in his actions; both men exemplified the purpose epitomized in Aubrey, a man of religion and law

Constant to's principles; and though the times

Made his worth sin, and his pure vertues crimes,

He stood unmov'd spite of all troubles hurl'd,

And durst support, but not turn with the World. (I, 299)

Brome's unqualified praise of constancy is not inconsistent with his support of moderation. Like many of his countrymen who trimmed their sails with the prevailing winds, Brome acknowledges the wisdom of caution and foresight; unlike them, however, he never changes his allegiance or ceases to admire traditional values. Although heroic fortitude and patient suffering are rarely encountered in Brome's world, his poems praise both in the abstract and in individuals the ability to accept all things with Lucian's "equal mind" and, in the words of Ecclesiastes, to "rejoice in his own works." When his poems seem to qualify this wisdom or when Brome appears to opt for the safety of the "middle" himself, the shift is toward survival and not cynicism. Without lapsing into the amoral greed of "The Polititian" his political poems value a disengagement based perhaps on fatalism but not defeatism. The diversity of his songs and ballads reflects, in short, the misgivings of a realist who longs for peace and order. This sensibility resists simple, reductive definition, but it is epitomized in one of his last and most interesting political poems, "A Speech made to the Lord General Monck."

Though much of the poem celebrates Monck as a redeemer who "Atlas- 
like" will support the country, the praise is often couched in negative terms. By assuring Monck that as military leader he will never compromise his nobility and will never ignore the dangers accompanying high position, the poem seems to disclose its author's doubts. The fears might well be the natural reaction of a royalist anxious to restore the monarchy and to avoid another Cromwell, but they surely also reflect the realities seen in the poem's rueful account of the greed and futility that characterized two decades of revolution. Without minimizing Monck's great qualities or discouraging his role in the country's restoration, the poem tactfully tries to confront the dark side of the human condition. In two other poems written for the "Generals Entertainment," Brome captures the evident joy in the prospect of an end to the nation's madness; ${ }^{24}$ in this poem, however, he is cautious. Both moods encompass the extremes of feeling in the era and in the poet.

In coming to terms with the reality that "In this round World, / All things are by a revolution hurl'd" (I, 336), Brome's political poems embrace anew the wisdom of this paraphrase of Ecclesiastes. Unlike the poetic legacy of Lovelace, who also suffered the destruction of the royalist cause, Brome's poetry offers no memorable romantic lines of triumph and defeat. While Lovelace languished in prison and lived in poverty, Brome pursued a successful legal career, taking time to write in varied voices about his country's crisis. The light, witty songs most commonly associated with Brome convey an easy, untroubled attitude readily summarized in the famous lines from Ecclesiastes, "Then I commended mirth, because a man hath no better thing under the sun, then to eat, and to drink, and to be merry." But taken as a whole, the political poems reveal a deeper understanding of this biblical wisdom. Sceptical and realistic, lighthearted and facile, Alexander Brome deserves to be recognized as a writer whose various moods and forms gloss in poetic terms the knowledge stressed in sixteenth-and seventeenth-century biblical commentaries on this passage: "Therefore mock thou the worlde as it mocketh thee. Dooe thine endeauour and duety, and let goe cares and sorrowfulness. Be of good cheare \& meary, knowing that the world useth not to rewarde \& consider the good."'25

\section{The University of Connecticut}

\section{Notes}

1 Gerard Langbaine, An Account of the English Dramatick Poets (Oxford, 1691), p. 32.

2 Edward Phillips, Theatrum Poetarum (London, 1675), II, 6.

3 Langbaine, p. 32.

4 The only complete study of Brome is J.L. Brooks' unpublished dissertation, Alexander Brome: Life and Works, Diss. Harvard, 1932. Roman R. Dubinski discusses the "psychological complexity" of Brome's love poetry in "The Scientific Element in Alexander Brome's Love Poetry," English 
Studies in Canada, 2(1976), 8-26; and C.V. Wedgwood briefly considers Brome's political poetry in Poetry and Politics under the Stuarts (Cambridge: Cambridge University Press, 1960). Professor Dubinski's edition Alexander Brome Poems (Toronto: University of Toronto Press, 1982), which appeared after this essay was accepted for publication, also considers the political poems (I, 22-29). This edition will be cited hereafter in the text.

5 F.L.C. Hearnshaw notes in "Court and Parliament 1588-1688," "Alexander Brome wrote a long series of political songs and ballads which will repay the careful study of those who are seeking to discover contemporary opinion concerning the great schism"-- English History in Contemporary Poetry (London: The Historical Association, 1969), p. 30.

6 "To Colonel Lovelace on his Poems," I, 89-90, and “To C.C. Esquire," I, 248-250.

7 Wedgwood, p. 108.

8 James Howell graphically captures the plight of the country caught in "this unnatural, selfdestroying war" in England's Tears for the present Wars (1644) in Somers Tracts (London, 1811 ), V. Ballads and songs expressing a similar dismay can be found in various collections; see, for example, "Thankes to the Parliament," "A Godly Exhortation," and "Alas poore Trades-men" in Cavalier and Puritan, ed. Hyder E. Rollins (New York: New York University Press, 1923) and "A Mad World my Masters" and "The Power of the Sword" in A Collection of Loyal Songs Written against the Rump Parliament, Between the Years 1639 and 1661 (London, 1731).

9 "To the Kings most Sacred Majesty, on his miraculous and glorious return 29. May, 1660," I, 358-67.

10 Francis Quarles, Solomons Recantation, Entituled Ecclesiastes, Paraphrased (London, 1645) in The Complete Works in Prose and Verse of Francis Quarles, ed. Alexander B. Grosart (Blackburn, England, 1880), II, 171.

11 Or as Douglas Bush defines it, the "cavalier trinity, beauty, love and loyal honour"-English Literature in the Earlier Seventeenth Century 1600-1660 (New York: Oxford University Press, 1962), p. 122.

12 The exceptions are "To his Mistres affrighted in the wars" and "Though Oxford be yielded." Both are set pieces.

13 See, for example, Francis Wortley's "The contented Prisoner his praise of Sack," which J. Woodfall Ebsworth notes is "the earliest appearance in print, known to us, of this characteristic outburst of Cavalier vivacity," pp. 93-96 in Choyce Drollery (Boston, England, 1876). Brome develops the conceit in such poems as "The Good-fellow," "The Companion," "Copernicus," and "The Painters Entertainment."

14 But often wine vies with royalty for the supreme allegiance; see "The New-Courtier," "The Prisoners," and "The Answer" to "The Mock Song, by T.J."

15 Other poems in this vein include "A Mock-song," "The Trouper," "The Prodigal," and "Copernicus."

16 The speaker in "The Independents Resolve" is the exception, but his exaltation of the power inherent in victory does not sit well with Brome's sympathies. The speaker cares nothing for religion and law, for he now holds the country in his grasp and threatens to consume the nation. Greed displaces the carefree pleasure associated with the cry "Come, drawer," and by the end of the poem the rapacious speaker longs to quaff "cordial gold."

17 Martin Luther, An Exposition of Salomons Booke, called Ecclesiastes (London, 1573), p. 7r, Thomas Granger, A Familiar Exposition or Commentarie on Ecclesiastes (London, 1621), p. 69; Michael Jermin, A Commentary, Upon The Whole Booke of Ecclesiastes or the Preacher (London, 1639), p. 299, See also William Pemble, Salomons Recantation and Repentance (London, 1632), p. 14; John Cotton, A Briefe Exposition with Practical Observations upon The Whole Book of Ecclesiastes (London, 1654), p. 189.

18 "The Reformation," I, 165, and "The Advice," I, 177; other poems advocating laughter include "The safe Estate" and "The New Gentry."

19 "The New Gentry," I, 158.

20 Arthur Jackson, Annotations Upon the Book of Ecclesiastes Or the Preacher in Annotations upon the Five Books (London, 1658), II, 2. 


\section{Renaissance et Réforme / 51}

21 "A new years gift," I, 272. Brome's critical judgement of Cromwell is unmistakable in "Cromwell's Panegyrick, upon his riding in triumph over the baffled City of London," I, 348-50.

22 "To C.S. Esquire" ('I've waited long to find thee here"), I, 248.

23 "To his reverend Friend Dr. S. on his pious and learned book," I, 287.

24 "For General Monk his entertainment at Cloath-workers Hall," I, 175; "For the Generall's entertainment," I, 165-66.

25 Luther, p. 143r. For similar interpretations of verse 8:15 see also Jermin, p. 2; Jackson, II, 82. 